\title{
SECONDARY IRON MINERALS PRESENT IN AMD SEDIMENTS FROM SMOLNÍK ABANDONED MINE
}

\author{
ZUZANA DAKOS ${ }^{1}$, DANIEL KUPKA ${ }^{1}$, MICHAL KOVAŘÍK ${ }^{1}$, \\ KATARÍNA JABLONOVSKÁ ${ }^{1}$, VÁCLAV KRIŠTÚFEK ${ }^{2}$, \\ MARCELA ACHIMOVIČOVÁ ${ }^{1}$ \\ ${ }^{1}$ Institute of Geotechnics of the Slovak Academy of Sciences, Košice, \\ Slovak Republic,(dankup@saske.sk) \\ ${ }^{2}$ Institute of Soil Biology of the Academy of Sciences of the Czech Republic \\ Na Sadkach 7, 37005 České Budejovice, Czech Republic
}

\begin{abstract}
The genesis of acid mine drainage (AMD) is conditioned by existence of indigenous chemolithotrophic iron and sulfur oxidizing bacteria, especially of genus Acidithiobacillus. The result of the oxidizing weathering of metal sulfides is a sequential formation of ochreous precipitates in drainage systems and in the surroundings of AMD seepage on the surface. The long-term monitoring of AMD waters collected at the shaft Pech that receives the majority of waters draining the flooded Smolník mine area point out the enduring contamination risk of particular components in the environment of Smolník mine area. Elemental analysis, X-ray diffraction, Mossbauer spectroscopy and scanning electron microscopy of the ochreous precipitates formed from Smolník AMD stream revealed schwertmannite as the dominant solid phase in the precipitates. The chemical analysis of AMD effluents and the elemental composition of related sediments indicated considerable scavenging potential of the ochreous precipitates towards metal cations and oxyanions of arsenic and sulfate.
\end{abstract}

Key words: Acidithiobacillus, acid mine drainage (AMD), ochreous precipitates, schwertmannite

\section{Introduction}

Extremely acidic environment $(\mathrm{pH}<3)$ occurs naturally, though they are more frequently associated with human activities, particularly the mining of coals and metal ores (JOHNSON, 1991). The biotic component of these environments is predominantly microbiological. Accordingly most research interest has focused on the iron-oxidizing bacteria (genus Acidithiobacillus) since their metal mobilizing activities are exploited in the biological processing of sulphidic ores, and also because their oxidation of mineral sulfides is a primary cause of acid mine drainage formation (NORRIS, 1990). The result of microbial oxidation of metal sulfides in oxic zones is the formation of acidic, metal laden drainage water and precipitation of secondary weathering products, primarily schwertmannite and minerals of the jarosite group. The precipitation of ferric iron as $\mathrm{Fe}^{(\mathrm{III})}$-hydroxysulfates is $\mathrm{pH}$-dependent, and the chemical composition of AMD effluents also greatly influences the mineralogical composition of forming precipitates (BIGHAM and NORDSTROM, 2000). The $\mathrm{pH}$ range from 3.0 to 4.5 and sulfate concentrations in the range of 1000 to $3000 \mathrm{mg} \mathrm{l}^{-1}$ facilitate the schwertmannite formation, while lower $\mathrm{pH}$ values at sufficiently high $\left[\mathrm{SO}_{4}\right]^{2-}$ concentrations lead to jarosite formation. Furthermore, schwertmannite formation does not require the presence of monovalent or divalent cations and removes more ferric iron and fewer sulfates from the solution phase compared to jarosite precipitation 
(BIGHAM et al., 1994, BIGHAM, 1994). This work points out the correlation between aqueous geochemistry of AMD and ochreous precipitates. It also presents the results of the analysis of selected physical and chemical parameters of mine drainage and associated stream sediments at the abandoned Smolník deposit (East Slovakia).

\section{Materials and methods}

Samples of AMD were collected from the sampling site at the shaft Pech quarterly according to the Water Act No. 364/204 Coll. as amended by the Act No. 384/2009 Coll. and related legislative documents. The measurement of temperature, $\mathrm{pH}$ and redox potential were carried out in the field using a $\mathrm{pH}$ electrode and a combined Pt$\mathrm{Ag} / \mathrm{AgCl}$ redox electrode respectively. Water samples for the consequent analysis were acidified with concentrated $\mathrm{HNO}_{3}$. Metals dissolved in AMD were measured with atomic absorption spectrometry (AAS). Total dissolved solids (TDS) were determined gravimetrically and the sulfate concentration by nephelometric method with $\mathrm{BaCl}_{2}$.

Ochreous precipitates were collected from the bottom and walls of shaft Pech receiving the majority of waters draining the flooded Smolník mine area. The precipitates were washed with distilled water. The solid phase was separated by centrifugation, air dried and homogenized before the analysis. The chemical composition of solid samples was determined by AAS after digestion with concentrated $\mathrm{HNO}_{3}$ and $\mathrm{HCl}(1: 1)$ in a microwave digester.

XRD patterns were measured by Philips PW 1820 powder diffractometer with $\mathrm{CuK} \alpha$ radiation. The JCPDS PDF database was utilized for phase identification.

Mössbauer spectra were taken in transmission geometry at temperature $\mathrm{T}=293 \mathrm{~K}$. $\mathrm{A}{ }^{57} \mathrm{Co} / \mathrm{Rh} \gamma$-ray source was used. The velocity scale was calibrated relative to ${ }^{57} \mathrm{Fe}$ in $\mathrm{Rh}$. The Recoil spectral analysis software was used for the quantitative evaluation of the Mössbauer spectra.

Morphology of the solid precipitates was examined by cryo field-emission SEM JSM 7401-F (JEOL Ltd., Tokyo, Japan). The density of the precipitates was determined by pycnometric method and specific surface area by BET method (GEMINI 2360, Micromeritics, USA).

\section{Results and discussion}

The $\mathrm{pH}$ of the water effluent from the shaft Pech after the end of flooding (June 1994) was 3.1 and during the following years it increased to 3.7. It does not change either after intense rains. Concentrations of some alkaline earth metals, total dissolved solids, sulfates and heavy metals present in these water samples are depicted in Fig. 1. The column graphs indicate the AMD water quality immediately after the flooding of the Smolník mine, compared to average values of the monitored parameters during the period 1995-2010. The third column indicates seasonal variation of individual parameters in connection to intensive rainfall in June 2010. Fig. 2 shows ochreous precipitates from the AMD. The chemical composition of the precipitate is stated in Table 1 and 2. The Smolník precipitate sample contained $44.89 \% \mathrm{Fe}$ and 5.53\% S, 
yielding a molar Fe/S ratio of 4.7. This value is within the range of naturally occurring schwertmannites (BIGHAM et al., 1994).
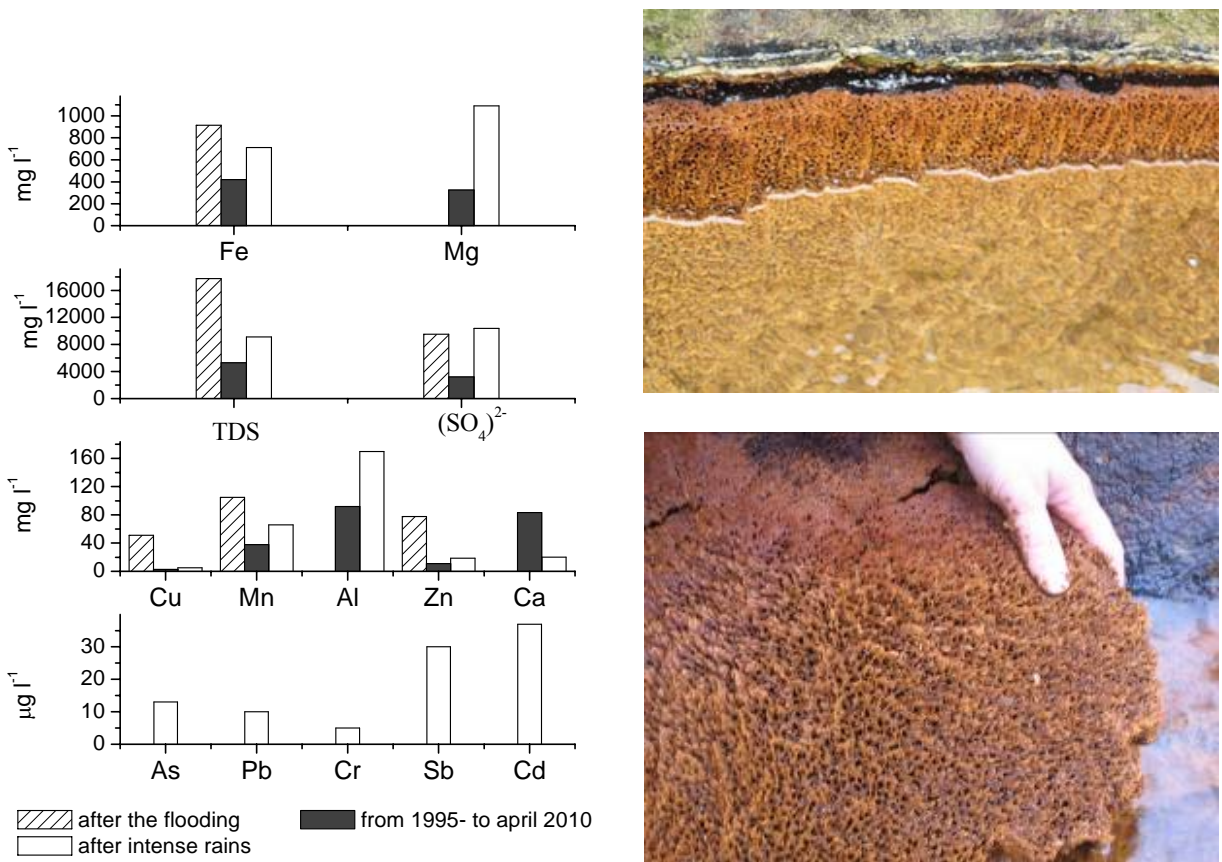

Fig. 1. Chemical analysis of water samples from shaft Pech

Fig. 2. Ochreous precipitates formed at the AMD flows bottoms and rims

Table 1. Chemical analysis of major elements in the ochreous precipitate collected from shaft Pech in Smolník abandoned mine. The values are in weight \%.

\begin{tabular}{ccccccc}
\hline Fe & S & Al & Ca & Mg & K & Na \\
\hline 44.89 & 5.53 & 0.38 & 0.1 & 0.07 & 1.13 & 0.02 \\
\hline
\end{tabular}

Table 2. Chemical analysis of heavy metals in the ochreous precipitate collected from shaft Pech in Smolník abandoned mine. The values are in ppm.

\begin{tabular}{ccccccccc}
\hline $\mathbf{A s}$ & $\mathbf{C u}$ & $\mathbf{M n}$ & $\mathbf{Z n}$ & $\mathbf{N i}$ & $\mathbf{C d}$ & $\mathbf{P b}$ & $\mathbf{C r}$ & $\mathbf{S b}$ \\
\hline 2800 & 700 & 210 & 235 & 16,3 & 0.7 & 1074.5 & 23.5 & 102 \\
\hline
\end{tabular}

Powder XRD analysis of schwertmannite can be readily distinguished from the associated minerals if specimens are reasonably pure. In the case of mixed assemblage with other minerals it may be difficult because of its poor crystallinity. The powder diffraction pattern of schwertmannite consists of eight broad peaks for $\mathrm{d}>1.4 \AA$ (BIGHAM and NORDSTROM, 2000). The strongest peak for natural sample (Fig. 3) occurs at about $2.54 \AA$ (212). Although it can be easily confused with the strongest peak of ferrihydrite, but its symmetrical character confirms the presence of schwertmannite as well as the reflection at $1.64 \AA$ (522), which is significantly displaced from that at $1.72 \AA$ for ferrihydrite. Distinct identification of two following 
reflections occurring at $2.27(302)$ and $1.94 \AA$ (113) is difficult, because the d-spacing characteristics for schwertmannite $(2.28$ and $1.95 \AA)$ very close to d-values characteristic for ferrihydrite $(2.21$ and $1.96 \AA)$. Similar situation occurs also in the case of reflections exhibited at 1.51 (004) and $1.45 \AA$ (204), but in the case of ferrihydrite, the intensity ratios are reversed. Furthermore, in contrast to ferrihydrite, schwertmannite exhibits two more reflections at 3.39 and $4.86 \AA$, from which the peak at $3.38 \AA$ (310) is detected on the XRD-pattern of natural sample. The d-values mentioned above responding to reference of schwertmannite [47-1775] were also confirmed by Rietveld LeBail profile matching technique (KUPKA et al. 2011).

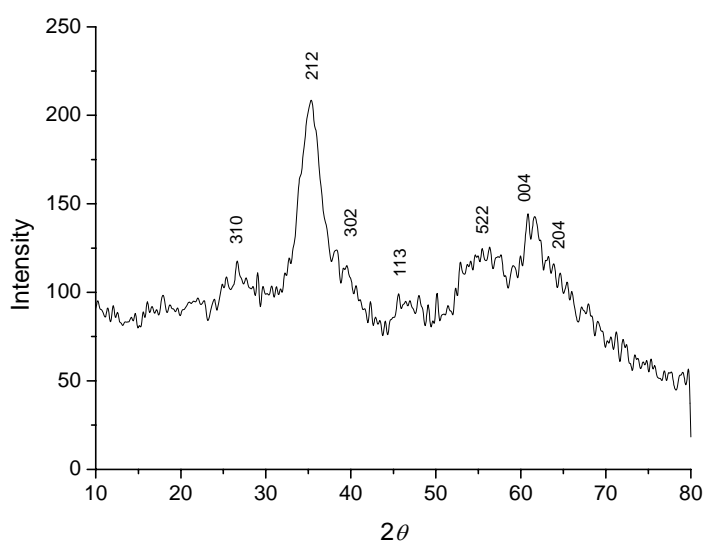

Fig. 3. X-ray diffraction analysis of the Smolník precipitate gave the characteristic schwertmannite pattern with broad peaks and a relatively high background.

The ${ }^{57} \mathrm{Fe}$ Mössbauer spectrum of natural sample measured at room temperature (Fig. 4) consists of an asymmetric doublet that was fitted with a combination of three ferric doublets with following Mössbauer parameters (Table 3). An average quadrupole splitting $0.69 \mathrm{~mm} / \mathrm{s}$ of these doublets is characteristic of schwertmannite (MURAD and CASHION, 2004).

Table 3. Mössbauer parameters, isomer shift (IS), quadrupole splitting (QS) and area of natural sample at $293 \mathrm{~K}$.

\begin{tabular}{cccc}
\hline Phase & IS [mm/s] & QS [mm/s] & Area [\%] \\
\hline Doublet 1 & 0.35 & 0.89 & 69 \\
Doublet 2 & 0.35 & 0.51 & 16 \\
Doublet 3 & 0.36 & 0.68 & 15 \\
\hline
\end{tabular}

The specific density of natural schwertmannite (precipitates settled down on the bottom of the AMD effluent channel) was $2.86 \pm 0.02 \mathrm{~g} . \mathrm{cm}^{-3}$. Specific surface area was $4.54 \pm 0.06 \mathrm{~m}^{2} \cdot \mathrm{g}^{-1}$. SEM and EDX analysis of schwertmannite is depicted in Fig. 5 and 6. SEM examination of the precipitate showed characteristic pin-cushion morphology of schwertmannite described by BIGHAM et al. (1994). 


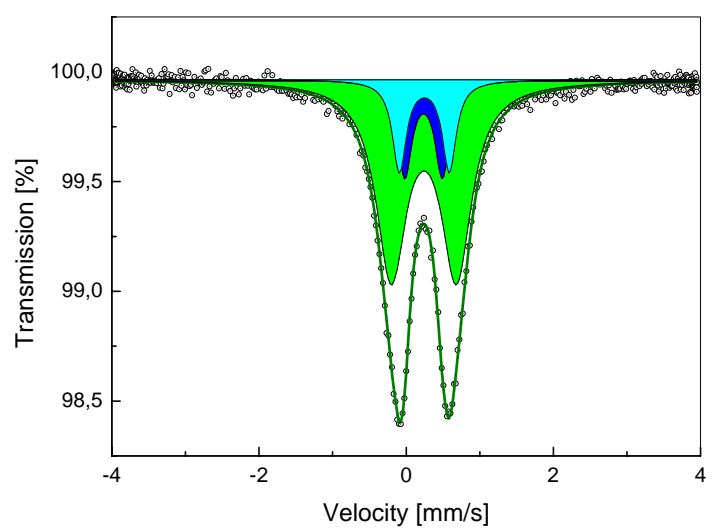

Fig. 4. Fitted ${ }^{57} \mathrm{Fe}$ Mössbauer spectrum of the Smolník precipitate.

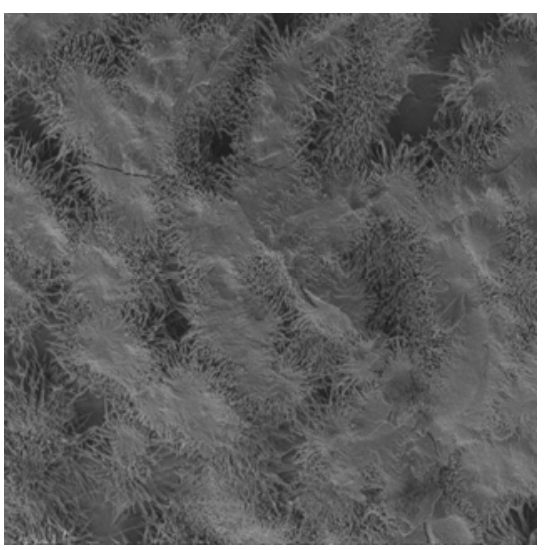

Fig. 5. SEM micrograph of the precipitate sample containing schwertmannite as the dominant mineral phase

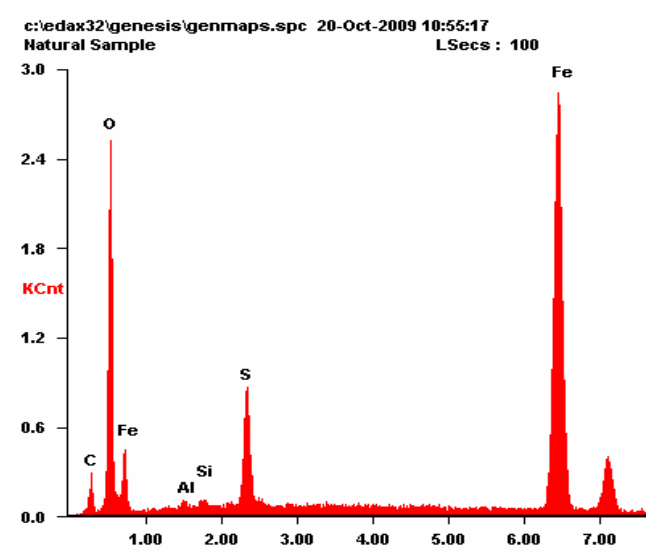

Fig. 6. EDX analysis revealed $69 \% \mathrm{Fe}, 5.72 \% \mathrm{~S}, 23.8$ $\% \mathrm{O}, 0.46 \% \mathrm{Al}$ and $0.39 \% \mathrm{Si}$ content in this mineral phase

\section{Conclusions}

This work deals with the correlation between the chemical composition of AMD and ochreous precipitates formation in them and their recipients in the presence of indigenous iron-oxidizing bacteria. The parameters of AMD effluent from the shaft Pech fit well the geochemical conditions which are conducive to iron precipitation as schwertmannite. In regard to the continuous surface and groundwater contamination, the need of solving the problem of water resources contaminated with acid mine drainage effluents is urgent and is calling for immediate attention.

The results acquired during this research provide information about the possibilities to use natural processes leading to formation of ochreous precipitates for attenuation of negative impact of AMD effluents on the environment. The bacterial iron oxidation step promotes the formation of ferric iron hydroxysulfate minerals that 
accommodate large quantities of iron and sulfate ions in their structure. Furthermore, the precipitates possess considerable scavenging potential for arsenic and other metal species. Fresh AMD precipitates are metastable and readily transform to thermodynamically more stable mineral forms. These interconversions modify the mobility and environmental impact of adsorbed and co-precipitated elements (CORNELL and SCHWERTMANN, 2003). Immediate separation of ferric sludge could prevent metals migration in both soluble and suspended form downstream from the contaminant source.

\section{Acknowledgment}

This work was supported by the Operational Programme Research and Development through the project: Centre of Excellence for Integrated Research of the Earth's Geosphere (ITMS: 26220120064), which is cofinanced through the European Regional Development Fund. And by the Slovak Grant Agency VEGA, Grant No. 2/0166/11).

\section{References}

BIGHAM J.M., CARLSON, L., MURAD, E.: Schwertmannite, a new iron oxyhydroxy- sulphate from Pyhäsalmi, Finland and other localities. Mineral. Mag., 58, 1994, 641-648.

BIGHAM J.M., NORDSTROM D.K.: Iron and aluminum hydroxysulfates from acid sulfate waters. Rev. Mineral Geochem., 40, 2000, 351-403.

BIGHAM, J.M.: Mineralogy of ochre deposits formed by sulfide oxidation. In: BLOWES, D.W., LAMBOR, J.L. (Eds.), The Environmental Geochemistry of Sulfide Mine-wastes. Mineralogical Association of Canada, Waterloo, Ontario, Canada, 1994, p. 103-132.

CORNELL, R.M, SCHWERTMANN, U.: The Iron Oxides. Wiley-VCH, Weinheim, 2003, ISBN 3-527-30274-3. 703 p.

JOHNSON, D.B.: Diversity of microbial life in highly acidic, mesophilic environments. In: Diversity of Environmental Biogechemistry (BERTHELIN, J., ed.), pp. 225-238, 1991, Elsevier, Amsterdam

KUPKA, D.: Effluent water quality and the ochre deposit characteristics of the abandoned Smolník mine, East Slovakia, Acta Montanistica (in press).

MURAD, E., CASHION, J.: Mössbauer Spectroscopy of Environmental Materials and their Industrial Utilization. Springer, Boston/Norwell, Massachusetts, USA, 2004, p. 418

NORRIS, P.R.: Acidophilic bacteria and their activity in mineral sulphide oxidation. In: Microbial Mineral Recovery (EHRLICH, H.L. and BRIERLEY, C.L., eds.), pp. 3-27, 1990, McGraw-Hill, New York.

Presented at the 2nd International Conference "Biotechnology and Metals - 2011", September 22-23, 2011, Košice, Slovak Republic. 